\title{
Investigating the Relationship between Vocabulary Size and Cultural Competence in English-Arabic Translation
}

\author{
By Maha Aldhahi* \\ Lloyd Davies" \\ Maria Fernández-Parra
}

\begin{abstract}
The translation of culture-bound expressions can be a challenge even for professional translators. This paper, therefore, explores the possibility of predicting the level of cultural competence needed in order to avoid translation errors by correlating cultural translation competence to vocabulary size. The results of our survey of Arabic professional translators show that vocabulary size was lower than expected, but vocabulary size can be an indicator of acceptable translation of culture-bound expressions, which we refer to as culture-bound items (CBIs). However, vocabulary size cannot always be used as an indicator of high quality translation. Overall, our results highlight the need for further cultural training for translators.
\end{abstract}

Keywords: culture-bound items, cultural competence, equivalence, formulaic sequences, vocabulary knowledge

\section{Introduction}

The literature on translation studies gives priority to the translator's acquisition of appropriate cultural knowledge which underpins the most basic professional standards in education. While there is much literature investigating the problems of the translating cultural expressions or content, not many studies seem to have focused on the importance of building cultural as well as linguistic knowledge both in the source language and the target language. Or even on investigating correlation between vocabulary knowledge and cultural knowledge which is our focus in this paper. Our findings contribute to the knowledge base in the field of linguistics and translation studies.

\section{Literature Review}

Several studies (Gläser 1984, Awwad 1990, Ghazala 2006, Baker 2011) have addressed the challenges of translating some types of CBIs such as metaphors, similes, idioms, proverbs, etc., while many others (e.g. Mustafa 2010, Faris and Sahu 2013, Mahdi and Yasin 2015) have focused on the problems of translation collocation. Other studies (Aziz 1985, 1999, Farghal and Borini 1996, Al-Masrai 2009, Abdel-Hafez 2004, Glodjovic 2010, Zanoletti 2012) have investigated CBIs in the literary, narrative and poetic

\footnotetext{
* PhD Student, Department of Languages, Translation and Interpreting, Swansea University, UK.

${ }^{\dagger}$ Associate Professor, Department of Languages, Translation and Interpreting, Swansea University UK.

* Lecturer, Department of Languages, Translation and Interpreting, Swansea University, UK.
} 
fields. Some research works (Barkho 1987, Shunnaq 2000) have discussed the political aspects of CBIs. Islamic CBIs have been also discussed in a few other studies (e.g. Awwad 1990, Faiq 1998, Homeidi 2004, Alghamdi 2016).

Furthermore, some studies (Alkadi 2010, Olwi forthcoming) have addressed CBIs in the media and the censorship applying to the translating of taboos CBIs. These studies have also investigated the fact that CBIs are perceived differently because of conflicting perceptions of CBIs associated with cultural differences. There are also studies (e.g. Ordudari 2007, Shamsaeefard et al. 2013, Ramli 2014, Pym 2016) that have discussed the solution to translating CBIs with reference to strategies, procedures, techniques and methods. While some studies have focused on the theory (Baker 2011) a few (Hickey 1998, Kehal 2010, Samardali et al. 2013) have investigated the pragmatic aspects and cultural problems in translation. Studies such as Bahumaid (2010) have developed instruments such as the Test of Cultural Competence in Translation (TCCT) to examine specific types of CBIs (metaphors, similes and proverbs).

There have also been studies which approach the problems of translating CBIs from the viewpoint of computer-assisted translation and machine translation (Fernandez-Parra 2014, Chung 2006, respectively). Chung emphasizes the importance of improving "traditional machine translators and cross-cultural communication aids". She states that it is necessary to "develop automated mechanisms to analyse cultural differences and similarities" (2006: 3).

Some studies (e.g. Mitchell 1994, Cometa 2004) investigate the link between image and word. Investigating the relation between the two, Cometa highlights their cultural significance and their potential influence on the text (Cometa 2004). Although these studies have a cultural perspective, they do not explain the image use on the text or its relationship with meaning as is often the case in translation studies.

Alowedi (2015) investigates the main elements (i.e. knowledge, skills and abilities) that Saudi translators in particular and translators in general need to attain professional competence. The aim is to enable translation organizations to assess translator competence. Alowedi (2015: 93) further addresses four groups of competences that the translator needs:

1. Extensive knowledge of both source and target cultures and languages: knowledge about historical, geographical, economic, religious general facts and political information about countries of the world; knowledge of culture specific to the language pair; knowledge of translation skills and professional practice (Bahumaid 2010). This is our focus in this paper.

2. Procedural skills: skills in searching for information; skills in using tools: translation, correction, etc.

3. Psycho-physiological abilities: cognitive skills such as analysis, problem solving, organisation, creativity.

4. Communication skills such as self-confidence, openness, collaboration. 
It should be noted that the first group of competences can be improved by learning through direct instruction about translation (Bahumaid 2010, Alowedi 2015), which the translation researchers can improve by addressing general facts (i.e. crises, values, celebrations beliefs), knowledge about culture-bound items in language pairs, knowledge about historical and geographical aspects of the SL and TL countries. The second group of competences can be improved by personal practice which depends on self-motivation. The third group of competences can be improved by the knowledge of the translator (cognitive). The fourth group of competences can be improved by general experience in any workplace (Alowedi 2015).

Therefore, this paper is an attempt to explore the first group of competences utilising both qualitative and quantitative methods. The paper begins by examining the linguistic knowledge of professional translators in both Arabic and English to establish whether there is a correlation between cultural competence and language knowledge by asking participants to translate the underlined 32 CBIs (see Appendix C). In this paper, we address CBIs as a subset of formulaic expressions (FE).

\section{Cultural Competence}

Among the many alternative umbrella terms proposed "culture bound", "culture bound terms", "culture bound expressions", and "culture bound elements", the term use in this paper is "culture bound items" (see Section Formulaic Sequences and CBIs). Culture bound items (CBIs) can be particularly difficult to translate, especially when translation occurs between two distinct languages and cultures, in our case those of the UK and Saudi Arabia. CBIs are prefabricated, conventionalized expressions, often with noncompositional meaning, that relate to a specific linguistic community within a given language (Ghazala 2006, Wray 2002). This definition also applies to same-language cultures, i.e. cultures that share a common language such as English in the case of the UK and the USA, or Arabic in the case of Saudi Arabia and Egypt. CBIs can vary between these cultures. For instance, the English CBI banana peel is mostly used in American English while the English CBI banana skin is mostly used in British English; thus, both these CBIs are typically used in one of these cultures only, either the American or the British.

Nonetheless, some of the CBIs are universal throughout the Englishspeaking world such as Indian summer, Valentine's Day and punk. The same occurs with the Arabic language; there are special CBIs for the Kingdom of Saudi Arabia (KSA), for instance, مرحباً ألف (back translation: thousand hello). This is an expression of welcome used in the southern region of Saudi Arabia. There are also other Arabic CBIs that are used in many Arabic speaking areas such as مسمار جحا/شعرة معاوية2back translations: like Juha's Nail ${ }^{1}$ and as

\footnotetext{
${ }^{1}$ A popular folklore story, that Juha sold his house except one nail. In the sale contract he stipulated that he can do whatever he wanted with the nail. Later, he came back many times at inconvenient times with a hammer in his hand and bangs the nail. Meaning: something becomes no more than a vacuous excuse.
} 
Mu'awaiah single hair $^{2}$ ). Also, there are CBIs that become universal between different cultures and languages due to overuse in political and social media such as fifth column and when in Rome do as the Romans do.

CBIs represent different aspects of culture such as history (Pardon my French), values (not everyone's cup of tea), customs and traditions (trick-ortreat), politics (House of Lords), sports (stir one's stumps) and so on. For this reason, translators need to be aware of CBIs and how they can be rendered from one language to another in both cultures. This includes looking at the similarities and differences (Aldhahi et al. forthcoming) between cultures in order to give a more effective equivalent. It may be that the CBIs in one language have equivalents in another language, but not all CBIs have equivalents in the target language; even if a linguistic equivalent exists, it does not necessarily mean that it is culturally equivalent.

Also, the image used in some CBIs may be acceptable in one culture but not necessarily in another, such as father in heaven, as drunk as a Lord and Jesus Christ; these would not be acceptable, for instance, in Saudi Arabian culture. These expressions illustrate that translating cultural specificity must be linked to the ethics of the target culture by working within the general principles of Skopos theory based on the principle that "a translation is determined by its purpose" (Nord 2005). Thus, the most adequate procedure can be determined depending on the similarities and differences of the images and meanings in CBIs between the two languages involved, and depending on the purpose of the translation (Aldhahi et al. forthcoming).

\section{Formulaic Sequences and CBIs}

Recent theories of processing a second language by native speakers confirm that processing a formulaic sequence is quicker and easier than that of "novel language" which is controlled by other factors such as length and single-word frequency (Wray 2002). Wray's definition of formulaic sequence is "a sequence, continuous or discontinuous, of words or other meaning elements, which is, or appears to be, prefabricated: that is stored and retrieved whole from the memory at the time of use, rather than being subject to generation or analysis by the language grammar" (2002: 9).

Wray argues that even single words and morphemes can be seen as formulaic sequences. For this reason, we present the CBI as a subset of Wray's concept of formulaic expression and investigate the associated challenges for the translator. Also, the degree of difficulty of the challenge will be discussed, i.e. the cultural content of an expression is a matter of degree and therefore some CBIs are easier to translate than others. In other words, if a formulaic expression has cultural content, it will be considered a CBI. The Oxford English Dictionary (OED) definition of culture-bound is "restricted in

\footnotetext{
${ }^{2}$ An old simile, that was said when Mu'awaiah (an Arabic leader) was asked about how he could manage his relationship with his people in a very difficult time. He said like a single hair, if the hair is tightened, he loosens it, if it is too loose, he tightens it, all in the interests of flexibility. The meaning is therefore the achievement of a balance between flexibility and strength.
} 
character or outlook by belonging or referring to a particular culture". Also, the OED definition of culture-bound is "limited by or valid only within a particular culture". In other words, all CBIs can be considered formulaic sequences but not all formulaic sequences are CBIs, as demonstrated in Figure 1.

Figure 1. CBIs within Formulaic Language

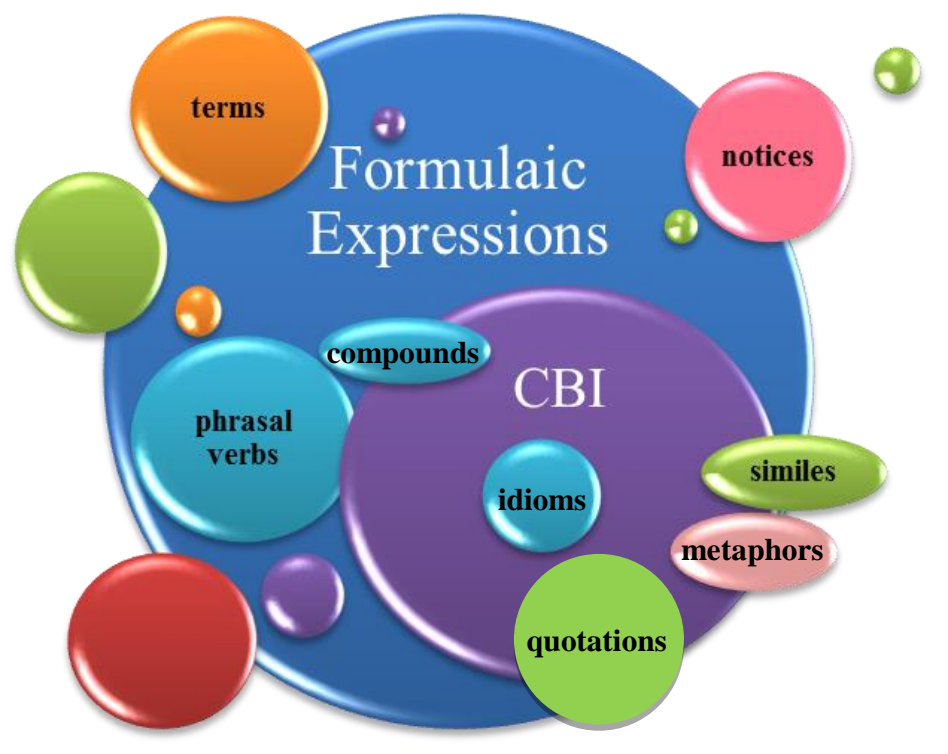

Based on Wray's definition of formulaic sequence, CBI is a "sequence" since we cannot change the order of CBIs such as the speaker of the House of Commons: the House of Commons speaker does not have the same meaning as the speaker of the Commons House. Also, CBIs are "prefabricated" which means they have become "conventional" and are not assembled or constructed by an individual. In addition, CBIs can be a single word such as punk, hooligan but can also be multi-word expressions such as Number 10 and can consist of expressions such as Madame Tussauds, golf widow and cream tea: these are all "stored and retrieved whole from the memory at the time of use" as is the case with formulaic sequences (Wray 2002), and these are all non-compositional. Finally, CBIs such as chop-chop and Love me, love my dog are not subject to "analysis by the language grammar". Therefore, we will consider CBIs as a type of formulaic sequence.

\section{Vocabulary Size and Language Competence}

Vocabulary knowledge is the essential building block of a language and without sufficient volume of vocabulary neither language production nor language comprehension is possible (Anglin 1993). A number of studies have linked vocabulary size to reading and listening comprehension, which are, arguably, important aspects of translation competence. For example, Nation (2006) proposes figures of 8,000-9,000 word families to understand authentic written texts and 6,000 to 7,000 to understand spoken discourse. In the same vein, Milton and Treffers-Daller (2013), argue that knowledge of around 
10,000 word families are needed for native English undergraduate students to understand academic materials.

In English there are figures which we can consult to set goals for learners and maybe translators, but these kinds of figures are scarce in Arabic. However, there is a study by Masrai and Milton (in press) in which they suggest that Arabic undergraduate students know, on average, 26,000 Arabic words. Hence, if Arabic undergraduate students have this level of knowledge then professional translators should possess greater vocabulary size in order to be competent. Knowing these vocabulary estimates in both English and Arabic can give us some insight into the potential language proficiency that professional translators should have. In this study, the language competence of translators was measured in addition to CBIs to find out if these measures are linked.

\section{Methodology}

There are two parts in this study: first, the assessment of participants' vocabulary knowledge in both English and Arabic, using XK-Lex test (Masrai and Milton 2012) and Arabic-Lex (Masrai and Milton in press). Second, the culture bound items test (CBIT). The tool used for this purpose was developed by the authors of the current study on the basis of the test of cultural competence in translation (TCCT) by Bahumaid (2010) who assesses the level of cultural competence in English-Arabic translator programmes in Arab universities.

The aim of the first part is to test the vocabulary size of Arabic professional translators in order to find out whether having high scores in vocabulary knowledge can be used as an indicator of high quality translation of culture-bound items. We assume that although vocabulary size might help to understand the overall meaning of a text, it cannot necessarily be used as an indicator of high quality translation and provide the deep meaning for a CBI. The first and the second tests (XK-Lex in English, Arabic-Lex) are to examine their Vocabulary knowledge of the source (i.e. Arabic) and target words (i.e. English). The second part is to examine their knowledge of cultural aspects in the target culture (TC) i.e. the UK, in different areas covering historic, geographic, political, economic, social, cultural, educational, legal, administrative aspects, etc.

Both the target language (TL) knowledge and CBIs are highly important for a high quality of translation. In general, the performance in both tests will help to find whether the high score in vocabulary size in both languages helps to translate the CBI or not. Also, the third test (i.e. the CBIT) is to measure the Arabic professional translators' ability to find the effective equivalent for the CBI; then the level of success in these translation challenges will be correlated with their level of vocabulary awareness. This focus is on validating the argument that getting a high score in the vocabulary tests implies translation competence in the English language. Also, it examines whether or not the education system in the Arabic country helped the translator to become culturally-equipped in the two cultures (i.e. SC and TC) without the need to be in the TC or whether the education system does not promote cultural awareness sufficiently. Can the education system alone help professional translators to enhance their cross-cultural 
awareness which in turn improves the quality of the translated text? The demographic set questions can clarify some of the outcomes from the two tests. These performances will provide accurate recommendations for the achievement of high-quality translation in the assimilation of CBIs.

\section{Participants}

A total of 35 Arabic professional translators participated in the study; 32 participants from KSA, and about 3 participants in the UK. The participants hold different education degrees (BA, MA, PhD), and they work in both the private and public sectors in KSA. The participants were targeted by social networks (i.e. forums websites, Twitter and LinkedIn).

\section{Instruments}

The survey was conducted including three sections using XK-Lex, ArabicLex and CBIT measures, beginning with a demographic set of questions. The sections are as follows:

The first section is the demographic set of questions to help us focus our study on those who are subject to our criteria. Also, it has been designed to determine the participants' cultural and language awareness by looking to different aspects such as: whether they are bilingual or not; determining their cultural and language performance, and, if bilingual, whether this leads to the third language which is a common "weakness" among professional translators everywhere. For instance in her translation of Javier Marías's Corazón tan blanco (A Heart so white), Margaret Jull Costa translates "Dio tres pasos más" as She gave three more steps the idiomatic form being, of course, She took three more steps (Marías 2012).

Also, some questions focus on location: whether participants live in the TC or not and if so, for how long in order to ascertain whether such factors contribute to their knowledge of CBIs in the TC (i.e. the UK). If they do not live in the TC, does their exposure to the source culture (SC) develop local knowledge in other ways or lead to "translationese" (Duff 1981).

Other questions were to explore their experience of specific areas of professional activity. We assume that those who work in the government sector have greater ability than those who work in the private sector because the selection process in Saudi Arabia is more demanding in the government sector. Also, a couple of questions focus on whether they use methods to enhance their translating outcome (e.g. association membership, translation mechanism tools, professional situations, personal skills and so on). Answering these questions will give us a clear picture about their cultural and language knowledge.

The second section is divided into two parts: (2/1) English vocabulary knowledge (measured using XK-Lex test) and (2/2) Arabic vocabulary knowledge (measured using Arabic-Lex test) (see Appendix A and Appendix B). Both the XK-Lex and Arabic-Lex are yes-no tests. They are based on word recognition, i.e. whether a participant believes he/she knows the given words. Both tests consist of 100 real words and 20 non-words; some of these words are real words in English 


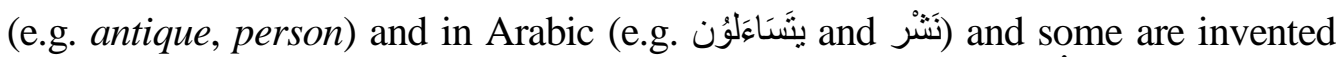

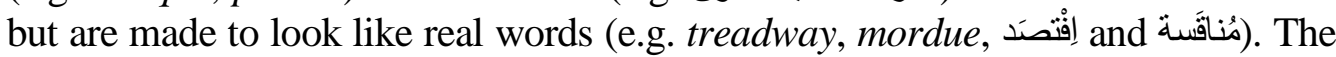
participants are asked to tick the words that they know. The only difference is that the Arabic-Lex measures the 50,000 most frequent words in Arabic and the XKLex measures the 10,000 most frequent words in English. This is because professional translators should be more competent in their native language. Professional translators are also assumed to have a good level of competence in their second language, so we provided the survey with the 10,000 most frequent words in English (Masrai and Milton 2012) which is designed for non-native English speakers who aim to study in an English-speaking country.

The third section is the CBIT test (see Appendix C). This tool focuses on items that pose cultural problems for translation from English (UK) into Arabic. Among these items are expressions which refer to every aspect of UK culture (e.g. sports, politics, religion, celebrations, etc.). There are 32 items in the test, each presented in one sentence except two items presented in one sentence, and participants are asked to give the equivalent translation to the underlined items. We chose 32 items to give a sufficient basis for a valid performance. It is possible that translators would be familiar with some of them but not all of them. Also, there is a need to have an adequate number of items to have a reliable tool. The data collected in this tool were based on works on British culture such as Christopher (2015), Smith (2012), Childs and Storry (2013), Hickey (1998) and a publication relating to procedures for acquiring British nationality, Life in the United Kingdom published by the British Home Office (Home Office 2013).

\section{Procedures}

Both surveys were designed on Survey Monkey in order to reach as many participants as possible in a short time: these surveys can be circulated to members in different networking programmes (e.g. LinkedIn, Twitter, email) and they are easy to use as they can be completed via mobile phones. There are questions in the demographic section which aim to determine if the participant is a professional translator or not in order to exclude those who are not professional translators. After the responses of the 35 participants had been collected and extracted to Excel sheets, the data were marked and processed using Statistical Package for the Social Sciences (SPSS) software (version 20).

\section{Results and Discussion}

In this section, we present the results of the analyses used to examine the aspects of reliability suggested by some researchers (e.g., Bachman 2004, Brown 2006) to examine our test. Also, we report the results of the participants' translation of the CBIs and discuss their competence in Arabic and English vocabulary tests.

This method has three benefits for the study: first, it helps to measure the Arabic professional translators' ability to find the effective equivalent for the CBI; 
second, it helps to identify the types of errors made by professional translators who are Arab native speakers in KSA and third, it measures their knowledge of the procedures that can be used to overcome challenges in translating CBIs. Finally, in order to examine the reliability of the results, two assessors were employed to evaluate the participants' performance in translating the CBIs.

\section{Demographic and Personal Characteristics}

This section presents the demographic and personal characteristics of the professional translators participating in the study and provides the response to the 16 questions in the demographic section (Tables 1 and 2).

Table 1 shows that Saudi accounted for 66\%, Lebanese, Palestinian and Jordanian for 9\% each and Egyptian, Yemeni, Sudanese for 3\% each. In general, all the participants were Arabic speakers. One of the respondents held a Diploma, while the majority (i.e. $40 \%$ ) held a BA and MA (i.e. 37\%) and about $11 \%$ held a $\mathrm{PhD}$. The majority, about $40 \%$, had 6-10 years of professional experience, $11.5 \%$ had more than 11 years of professional experience and 42.8 had less than 5 years of professional experience.

It was noted that $43 \%$ were working in the private sector and $46 \%$ in public sector. 91\% live in Saudi Arabia while $8.6 \%$ live in UK. However, about $11 \%$ have lived in an English-speaking country while about $27 \%$ have not worked in an English-speaking country. The majority (84\%) have lived in an English-speaking country for one year or less while about $9 \%$ have lived in such a country for 1-5 years.

Around $48.6 \%$ are not members of any translation associations, only $3 \%$ were member of ATA, $3 \%$ of ITI, $6 \%$ of CIOL and about $40 \%$ indicate that they belong to other associations. The next 6 questions regarding personal experience and knowledge are provided in Table 2 of the demographic section.

Almost all (82.9\%) of the participants believed that their studies helped them to improve their translation of CBIs, while $11 \%$ did not know and the rest (6\%) believed that it did not help them. The majority $(80 \%)$ of the translators use Google Translate apart from dictionaries, 8.6\% use Babylon and Bing Translator, only $3 \%$ of the participants use SYSTRAN, and about $14 \%$ use other programs; none use other programs such as OmegaT, Smart CAT, Déjà Vu, PROMT, Cute translator, NeuroTran, Asia Online, SDL Trados, etc.

About half $(48.5 \%)$ of the participants indicated that they use books to keeping up to-date with current affairs, 38\% use articles, 34\% use websites, $25.7 \%, 17 \%$ watch films and television programs and $14 \%$ use blogs.

The majority (74\%) indicated that the strategies they use to improve their translation quality and skills is to practise more; about $28.6 \%$ use computer tools and revision; $17 \%$ take more time in the translation process; and about $14 \%$ attend continuing education courses and seminars.

The results show that $65.7 \%$ of the participants choose the closest approximation in the target language to handle untranslatable words or expressions when translating and $28.6 \%$ provide an explanation of the cultural context in order to help the audience understand what the author is attempting to convey. 
Table 1. Demographic and Personal Characteristics of the Study Group

\begin{tabular}{|c|c|c|c|c|}
\hline ID & \multicolumn{2}{|l|}{ Characteristics } & $\mathbf{N}$ & Per Cent \\
\hline \multirow[t]{3}{*}{1} & Gender & Female & 24 & 68.6 \\
\hline & & Male & 4 & 11.4 \\
\hline & & Prefer not to say & 7 & 20 \\
\hline \multirow[t]{4}{*}{2} & Age & $21-30$ & 13 & 37.1 \\
\hline & & $31-40$ & 8 & 22.9 \\
\hline & & $41-50$ & 1 & 2.9 \\
\hline & & Prefer not to say & 13 & 37.1 \\
\hline \multirow[t]{7}{*}{3} & Ethnic & Saudi & 23 & 65.7 \\
\hline & & Lebanese & 3 & 8.6 \\
\hline & & Palestinian & 3 & 8.6 \\
\hline & & Jordanian & 3 & 8.6 \\
\hline & & Egyptian & 1 & 2.9 \\
\hline & & Yemeni & 1 & 2.9 \\
\hline & & Sudanese & 1 & 2.9 \\
\hline \multirow[t]{3}{*}{4} & L1 & Arabic & 35 & 100 \\
\hline & & English & 0 & 0 \\
\hline & & Bilingual & 0 & 0 \\
\hline \multirow[t]{5}{*}{5} & Education level & Diploma & 1 & 2.9 \\
\hline & & $B A$ & 14 & 40 \\
\hline & & $M A$ & 13 & 37.1 \\
\hline & & $P h D$ & 4 & 11.4 \\
\hline & & Missing response & 3 & 8.6 \\
\hline \multirow[t]{7}{*}{6} & Professional Experience & $0-1$ & 4 & 11.4 \\
\hline & & $1-5$ & 11 & 31.4 \\
\hline & & $6-10$ & 14 & 40 \\
\hline & & $11-15$ & 1 & 2.9 \\
\hline & & $16-20$ & 2 & 5.7 \\
\hline & & $36-40$ & 1 & 2.9 \\
\hline & & Missing response & 2 & 5.7 \\
\hline \multirow[t]{3}{*}{7} & What is your profession? & Private sector & 15 & 42.9 \\
\hline & & Public sector & 16 & 45.7 \\
\hline & & Other & 4 & 11.4 \\
\hline \multirow[t]{2}{*}{8} & Where do you live now? & $K S A$ & 32 & 91.4 \\
\hline & & $U K$ & 3 & 8.6 \\
\hline \multirow[t]{3}{*}{9} & Have you lived in an English-Speaking & Yes & 4 & 11.4 \\
\hline & country? & No & 27 & 77.1 \\
\hline & & Missing response & 4 & 11.4 \\
\hline \multirow[t]{3}{*}{10} & How many years have you been in the UK or in & $0-1$ & 26 & 84.3 \\
\hline & an English-speaking country? & $1-5$ & 9 & 15.7 \\
\hline & & 10 and above & 0 & 0 \\
\hline \multirow[t]{9}{*}{11} & Are you a member of any of these associations & None & 17 & 48.6 \\
\hline & or any others please indicate? & $A T A^{3}$ & 1 & 2.9 \\
\hline & & ITI & 1 & 2.9 \\
\hline & & CIOL & 2 & 5.7 \\
\hline & & $J T A$ & 0 & 0 \\
\hline & & $A L T A$ & 0 & 0 \\
\hline & & AUSIT & 0 & 0 \\
\hline & & СТTIC & 0 & 0 \\
\hline & & Other & 14 & 40 \\
\hline
\end{tabular}

3 USA: ATA: American Translators Association; ALTA: American Literary Translators Association; AUSIT: Australian Institute of Interpreters and Translators; Canada: CTTIC: The Canadian Translators, Terminologists and Interpreters Council; UK: ITI: Institute of Translation and Interpreting; CIOL: Chartered Institute of Linguists; Jordan: JTA: Jordanian Translators Association. 
Table 2. Personal Experience and Knowledge of the Study Group $(N=35)$

\begin{tabular}{|c|c|c|c|c|}
\hline ID & \multicolumn{2}{|c|}{ Characteristics } & $\mathbf{N}$ & Per Cent \\
\hline 12 & $\begin{array}{l}\text { Have your studies helped } \\
\text { you to improve your } \\
\text { translation of CBIs? }\end{array}$ & $\begin{array}{l}\text { Yes } \\
\text { No } \\
\text { I do not know }\end{array}$ & $\begin{array}{c}29 \\
2 \\
4\end{array}$ & $\begin{array}{c}82.9 \\
5.7 \\
11.4 \\
\end{array}$ \\
\hline 13 & $\begin{array}{l}\text { What resources do you use } \\
\text { to translate apart from } \\
\text { dictionaries? }\end{array}$ & $\begin{array}{l}\text { OmegaT } \\
\text { Smart CAT } \\
\text { Déjà Vu } \\
\text { Babylon } \\
\text { PROMT } \\
\text { Cute translator } \\
\text { NeuroTran } \\
\text { Asia Online } \\
\text { Google Translate } \\
\text { Bing Translator } \\
\text { SYSTRAN } \\
\text { 1-800-translate } \\
\text { WorldLingo } \\
\text { SAIC Omnifluent } \\
\text { SDL Trados } \\
\text { Other }\end{array}$ & $\begin{array}{c}0 \\
0 \\
0 \\
3 \\
0 \\
0 \\
0 \\
0 \\
28 \\
3 \\
1 \\
0 \\
0 \\
0 \\
0 \\
5 \\
\end{array}$ & $\begin{array}{c}0 \\
0 \\
0 \\
8.6 \\
0 \\
0 \\
0 \\
0 \\
80 \\
8.6 \\
2.9 \\
0 \\
0 \\
0 \\
0 \\
14.3 \\
\end{array}$ \\
\hline 14 & $\begin{array}{l}\text { What kind of resources do } \\
\text { you use to keep up-to-date } \\
\text { with current affairs? }\end{array}$ & $\begin{array}{l}\text { Newspaper } \\
\text { Books } \\
\text { Articles } \\
\text { Blogs } \\
\text { Websites } \\
\text { Watching movies/television }\end{array}$ & $\begin{array}{c}9 \\
34 \\
13 \\
5 \\
12 \\
6\end{array}$ & $\begin{array}{c}25.7 \\
48.5 \\
38 \\
14 \\
34 \\
17\end{array}$ \\
\hline 15 & $\begin{array}{l}\text { What strategy do you use } \\
\text { to improve your } \\
\text { translation quality and } \\
\text { skills? }\end{array}$ & $\begin{array}{l}\text { Revision } \\
\text { Take more time } \\
\text { Using computer tools } \\
\quad \text { Attend continuing education } \\
\text { courses and seminars } \\
\text { More practice }\end{array}$ & $\begin{array}{c}10 \\
6 \\
10 \\
5 \\
26\end{array}$ & $\begin{array}{c}28.6 \\
17 \\
28.6 \\
14 \\
74\end{array}$ \\
\hline 16 & $\begin{array}{l}\text { How do you handle } \\
\text { untranslatable words or } \\
\text { expressions when } \\
\text { translating? }\end{array}$ & $\begin{array}{l}\text { I choose the closest-approxima- } \\
\text { tion in the target language. } \\
\text { I ignore the word altogether. } \\
\text { I provide an explanation of the } \\
\text { cultural context in order to help the } \\
\text { audience understand what the } \\
\text { author is attempting to convey. }\end{array}$ & $\begin{array}{c}23 \\
0 \\
10\end{array}$ & $\begin{array}{c}65.7 \\
0 \\
28.6\end{array}$ \\
\hline
\end{tabular}

The Correlation between the Demographic Questions and the CBIT

This section clarifies the relationship between the demographic and personal characteristics of the participants in the study and their performance in translating the CBIT. The responses to the demographic and personal characteristics are given in Table 3.

As shown in Table 3, the correlation between gender and the CBIT is very low $(r=275)$, and the correlation between education level and the CBIT is very low $(r=-0.076)$, which means that no matter what their education level this in itself does not promote an adequate level of cultural awareness for the translator in Saudi Arabia. However, the findings show a positive significant correlation 
between the age and the CBIT ( $r=453)$, which might indicate that as they mature, the cross-cultural awareness of translators increase.

Also, Table 3 indicated that there is no correlation between the professionals who work in private or public sectors and their performance in CBIT $(r=-0.006)$. Further, there is no correlation between their cultural awareness and their years of professional experience $(r=-0.240)$. Significantly those who live in the SC or in the TC $(r=-0.020)$ do not improve thereby their cultural awareness; however, the number of participants who live in the TC is very low so this finding could not be confirmed. Again, the finding does not give any correlation for those who lived in the TC for long periods of time or not $(r=-0.061)$. On the other hand, the results show a significant correlation between translators belonging to a translation association and their performance in translating the CBIs, which emphasises the importance of such membership.

The results in Table 4 indicated that there is not any correlation between their performance and their responses regarding their experience or knowledge in cultural competence in translation process. A question about whether education system does help them to translate the CBIs most of the responses said yes while their performance indicates the opposite $(r=-0.133)$.

Another question regarded the resources used apart from dictionaries. The majority said they used Google translate, which do not help them in their translation of CBIs $(r=0.013)$. Furthermore, a question asked about the resources they use to on keeping them up to date with current affairs their responses vary between many of good resources however that do not help them in translating CBIs $(r=-0.168)$. In response to questions about the strategy they use to improve their translation quality and skills most mentioned revision and the use of computer tools. Their responses do not show a clear correlation with their cultural competence $(r=-0.195)$.

The last question concerns how they handle untranslatable words or expressions when translating. More than half said that they choose the closest approximation in the target language and about $28 \%$ said that they provide an explanation of the cultural context in order to help the audience understand what the author is attempting to convey, however that did not help them in translating the CBIs $(r=0.160)$.

The finding in the demographic section highlights the need to address the CBIs in the education system in the KSA in order to help the translator become culturally-equipped in the TC whatever their level of education (i.e. BA, MA and $\mathrm{PhD}$ ). Also demonstrated was the importance of introducing different computer tools in the education system which in turn improves the quality of the translation in the Saudi Arabia. More important is to have a translation association in Saudi Arabia and encourage translators to obtain membership. 
Table 3. Correlation between the Demographic and Personal Characteristics and CBIT

\begin{tabular}{|c|c|c|c|c|c|c|c|c|c|c|}
\hline & & CBI & Gender & Age & $\begin{array}{c}\text { Level of } \\
\text { Education }\end{array}$ & $\begin{array}{c}\text { Private or } \\
\text { public sectors }\end{array}$ & $\begin{array}{c}\text { Years of professional } \\
\text { experience }\end{array}$ & \begin{tabular}{|c|} 
Living \\
situation
\end{tabular} & $\begin{array}{l}\text { Years in } \\
\text { the } T C\end{array}$ & $\begin{array}{c}\text { Member of any associations } \\
\text { of translation }\end{array}$ \\
\hline \multirow[t]{3}{*}{ CBI } & $\begin{array}{l}\text { Pearson } \\
\text { Correlation }\end{array}$ & 1 & 0.275 & $0.453^{-}$ & -0.006 & -0.006 & -0.240 & -0.020 & -0.061 & $-0.405^{*}$ \\
\hline & Sig. (2-tailed) & & 0.142 & 0.034 & 0.971 & 0.971 & 0.179 & 0.909 & 0.791 & 0.016 \\
\hline & $\mathrm{N}$ & 35 & 30 & 22 & 35 & 35 & 33 & 35 & 21 & 35 \\
\hline
\end{tabular}

4*. Correlation is significant at the 0.05 level (2-tailed).

Table 4. Correlations between Personal Experience and Knowledge and the CBIT

\begin{tabular}{|c|c|c|c|c|c|c|c|}
\hline & CBI & $\begin{array}{c}\text { Education } \\
\text { system }\end{array}$ & $\begin{array}{c}\text { Resources } \\
\text { used }\end{array}$ & $\begin{array}{c}\text { Resources for } \\
\text { current affairs }\end{array}$ & $\begin{array}{c}\text { Strategy to } \\
\text { improve their } \\
\text { skills }\end{array}$ & $\begin{array}{c}\text { Their strategies to handle } \\
\text { untranslatable words }\end{array}$ \\
\hline & $\begin{array}{c}\text { Pearson } \\
\text { Correlation }\end{array}$ & 1 & -0.133 & 0.013 & -0.168 & -0.195 & 0.160 \\
CBI_Correct & Sig. (2-tailed) & & 0.447 & 0.942 & 0.334 & 0.261 \\
& $\mathrm{~N}$ & 35 & 35 & 35 & 35 & 35 \\
\hline
\end{tabular}

\footnotetext{
${ }^{4}$ The significance level (or p-value) is the probability of obtaining results as extreme as the one observed. If the significance level is very small (less than 0.05 ) then the correlation is significant and the two variables are linearly related. If the significance level is relatively large (for example, 0.50 ) then the correlation is not significant and the two variables are not linearly related.
} 
The Reliability of the CBIT: Preliminary Analysis

Initially, the reliability of the CBIT was tested by comparing the scores obtained from two assessors (i.e. CBIT_1 and CBIT_2). The participants in this first stage of validation were professional translators. The results indicate a strong correlation ( $r=0.988)$ between the two evaluates CBIT_1 and CBIT_2 of the test. The correlation is highly significant at $(P<0.001)$. Further analyses were carried out to investigate internal consistency and reliability. Table 5 presents paired sample statistics that summarise the mean, standard deviation and standard mean deviation of errors for scores of different assessors of the test.

Table 5. Paired Sample Statistics of CBIT Assessors

\begin{tabular}{|l|l|c|c|c|c|}
\hline \multicolumn{2}{|c|}{} & Mean & N & Std. Deviation & Std. Error Mean \\
\hline \multirow{2}{*}{ Pair 1 } & CBIT_1 & 5.5714 & 35 & 4.18882 & 0.70804 \\
\cline { 2 - 6 } & CBIT_2 & 5.3143 & 35 & 4.49687 & 0.76011 \\
\hline
\end{tabular}

The results show that the mean scores in the two assessors (CBIT_1 $=5.5714$ and CBIT_2 $=5.3143$ ) of the test are very close to each other. This finding provides evidence to support the test's capacity to predict test-takers' performances in a reliable manner. This part of the results suggests that the CBIT has high levels of reliability in terms of parallel rating and internal consistency for one assessor of the test. To avoid any impression that these results were obtained by chance and in order to confirm our findings, a t-test was performed for the data. The t-test scores are reported in Table 6.

Table 6. Paired Samples Test

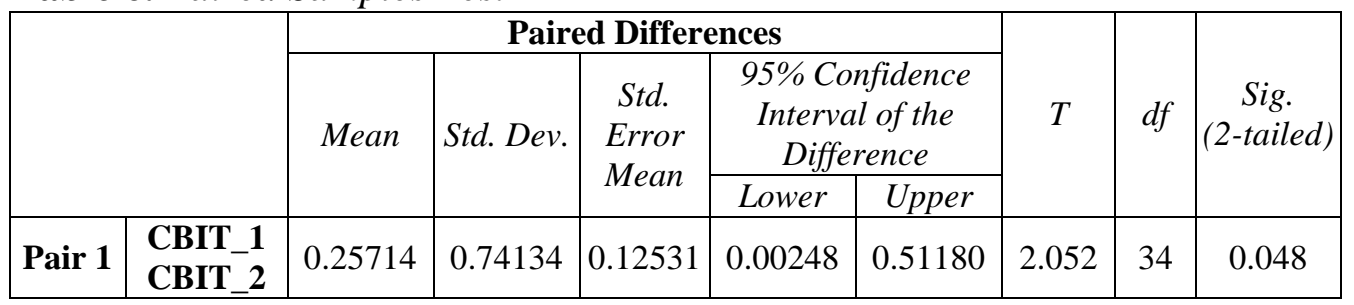

The t-test indicates that the differences between the two assessors (i.e. CBIT_1 and CBIT_2) of the test are not statistically significant. To examine further whether the test is working in the estimated manner, correlation coefficient analysis was accompanied for the pair described in Table 7. The results reported in Table 7 show that the correlation coefficients between the test pairs are positively high. 
Table 7. Paired Samples Correlations

\begin{tabular}{|c|c|c|c|c|}
\hline \multicolumn{2}{|l|}{} & N & Correlation & Sig. \\
\hline Pair 1 & CBIT_1 \& CBIT_2 & 35 & 0.988 & 0.000 \\
\hline
\end{tabular}

This evidence further suggests that the test is performing largely in the way it should be, given the purpose for which it was created. The final reliability measure for the CBIT was Cronbach's alpha analysis (Table 8).

Table 8. Reliability Statistics

\begin{tabular}{|c|c|c|}
\hline Cronbach's Alpha & $\begin{array}{c}\text { Cronbach's Alpha Based on } \\
\text { Standardized Items }\end{array}$ & N of Items \\
\hline 0.993 & 0.994 & 2 \\
\hline
\end{tabular}

The figures reported in Table 8 show high reliability indices for the test pair (above 0.90). According to DeVellis (2016), the alpha score is very good when it falls between 0.80 and 0.90 and excellent when it is above 0.90 . After finding these preliminary results, the descriptive statistics for professional translators' scores in both XK-Lex test and Arabic-Lex test were calculated. These scores were compared with their scores in CBIT.

\section{Relationship between Scores from XK-Lex, Arabic-Lex and CBIT}

Table 9 summarizes the minimum, the maximum, the mean scores and the standard deviation of the Arabic professional translators' levels in English vocabulary knowledge, Arabic vocabulary knowledge and CBIT.

Table 9. Descriptive Statistics for XK-Lex, Arabic-Lex and CBIT

\begin{tabular}{|c|c|c|c|c|c|}
\hline & N & Minimum & Maximum & Mean & Std. Deviation \\
\hline XK-Lex & 35 & 16 & 90 & 65.31 & 15.628 \\
\hline Arabic-Lex & 35 & 31 & 93 & 70.71 & 14.008 \\
\hline CBIT & 35 & 3.00 & 53.00 & 17.4000 & 13.04393 \\
\hline Valid N (listwise) & 35 & & & & \\
\hline
\end{tabular}

The results in Table 9 show that the mean score for the CBIT is low indicating that the translators, on average, have managed to translate correctly just over $17 \%$ of the total items. On the other hand, their mean score in English knowledge is 65\% (about 6,500 words) and in Arabic knowledge it is 70\%. According to Nation (2006), the vocabulary size of 8,000-9,000 word families is required to comprehend written discourse. Translators' scores in English appear lower than the knowledge proposed by Nation. However, the results report that even if the participants got high scores in XK-Lex and Arabic-Lex, they did not achieve a high score in the CBIT which confirms our argument that vocabulary size cannot always be used as an indicator of high quality translation. 


\section{The Correlation between XK-Lex, Arabic-Lex and CBIT}

Pearson correlations ${ }^{5}$, as shown in Table 10, the results indicate a positive significant correlation between the Arabic score and English score $(r=0.517)$. The results also show a positive correlation $(r=0.493)$ between English competence and translating CBI. Finally, the findings show a positive significant correlation between Arabic knowledge and translation of the CBIs $(r=0.368)$.

Table 10. The Correlation between XK-Lex, Arabic-Lex and CBIT

\begin{tabular}{|cc|c|c|c|}
\hline & & XK-Lex & Arabic-Lex & CBIT \\
\hline & Pearson Correlation & 1 & $\mathbf{0 . 5 1 7 ^ { * * }}$ & $\mathbf{0 . 4 9 3}$ \\
XK-Lex & Sig. (2-tailed) & & 0.002 & $\mathbf{0 . 0 0 3}$ \\
& N & 34 & 34 & 34 \\
\hline \multirow{3}{*}{ Arabic-Lex } & Pearson Correlation & $\mathbf{0 . 5 1 7 ^ { * * }}$ & 1 & $\mathbf{0 . 3 6 8}$ \\
& Sig. (2-tailed) & $\mathbf{0 . 0 0 2}$ & & $\mathbf{0 . 0 3 2}$ \\
& N & 34 & 34 & 34 \\
CBIT & Pearson Correlation & $\mathbf{0 . 4 9 3}$ & $\mathbf{0 . 3 6 8}$ & 1 \\
& Sig. (2-tailed) & $\mathbf{0 . 0 0 3}$ & $\mathbf{0 . 0 3 2}$ & \\
& N & 34 & 34 & 34 \\
\hline
\end{tabular}

**. Correlation is significant at the 0.01 level (2-tailed).

*. Correlation is significant at the 0.05 level (2-tailed).

The results in Table 10 show that it is possible to predict the level of cultural competence needed in order to avoid translation errors by correlating cultural translation competence to English and Arabic vocabulary knowledge. This means that if the professional translator has a high score in Arabic vocabulary it can help him/her to be competent in English which in turn can help him/her to predict the meaning of the CBI by understanding the whole text even if they did not give the equivalence for the CBI in the TL but at least can avoid the serious errors. To examine the data more closely, further analyses using linear regression model was performed to check whether having high scores in XK-Lex and Arabic-Lex can predict the performance in CBIT. The results are summarized in Table 11.

Table 11. Model Summary

\begin{tabular}{|c|c|c|c|c|}
\hline Model & $\mathbf{R}$ & $\mathbf{R}^{2}$ & Adjusted R $\mathbf{R}^{\mathbf{2}}$ & SE of estimate \\
\hline 1 & $0.510^{\mathrm{a}}$ & 0.260 & 0.213 & 11.68799 \\
\hline
\end{tabular}

a. Predictors: (Constant), XK-Lex, Arabic-Lex.

The results in Table 11 indicate that vocabulary knowledge in English and Arabic combined can explain about 26\% (Multiple $\mathrm{R}^{2}=0.260$ ) of the total variance in CBI. Further, analysis using ANOVA test (Table 12) to find out whether there is a statistically significant differences between vocabulary knowledge and achieving high scores on CBIT, thus we can reject the null hypothesis that "the model has no predictive value."

\footnotetext{
${ }^{5}$ The Pearson correlation coefficient is used to measure the strength of a linear association between two variables where the value $r=1$ means a perfect positive correlation and the value $r=-1$ means a perfect negative correlation (Fenton and Neil 2012).
} 
Table 12. $A N O V A_{a}$

\begin{tabular}{|ll|c|c|c|c|c|}
\hline \multicolumn{1}{|c|}{ Model } & $\begin{array}{c}\text { Sum of } \\
\text { Squares }\end{array}$ & Df & $\begin{array}{c}\text { Mean } \\
\text { Square }\end{array}$ & F & Sig. \\
\hline 1 & Regression & 1490.560 & 2 & 745.280 & 5.456 & $0.009^{\mathrm{b}}$ \\
& Residual & 4234.881 & 31 & 136.609 & & \\
& Total & 5725.441 & 33 & & & \\
\hline
\end{tabular}

a. Dependent Variable: CBIT.

b. Predictors: (Constant), XK-Lex, Arabic-Lex.

In Table 12, the ANOVA produces a $P$ value of 0.01 which lies below all $\alpha$ values. So, one could conclude that the score of CBIT for Arabic professional translators changes significantly with respect to their score in the English and Arabic vocabulary size tests.

Table 13 evaluates each of XK-Lex and Arabic-Lex depending on their performance on CBIT. We use the column labelled standardized coefficients as we are interested in comparing the contribution of XK-Lex and Arabic-Lex in translating the CBIs by using the beta values.

Table 13. Coefficients

\begin{tabular}{|c|l|c|c|c|c|c|}
\hline \multirow{2}{*}{ Model } & \multicolumn{2}{|c|}{$\begin{array}{c}\text { Unstandardized } \\
\text { Coefficients }\end{array}$} & $\begin{array}{c}\text { Standardized } \\
\text { Coefficients }\end{array}$ & \multirow{2}{*}{ T } & \multirow{2}{*}{ Sig. } \\
\cline { 3 - 5 } & B & Std. Error & Beta & & \\
\hline \multirow{3}{*}{1} & (Constant) & -21.751 & 12.739 & & -1.707 & 0.098 \\
\cline { 2 - 7 } & XK-Lex & 0.411 & 0.179 & 0.413 & 2.291 & 0.029 \\
\cline { 2 - 7 } & Arabic-Lex & 0.160 & 0.188 & 0.154 & 0.854 & 0.400 \\
\hline
\end{tabular}

a. Dependent Variable: CBIT.

In Table 13, the largest beta coefficient is 0.413 , which is for the XK-Lex. This means that English vocabulary knowledge makes the strongest unique contribution to explaining the CBIT, while the beta value for the Arabic-Lex is slightly lower (0.154), indicating that it made less contribution. To conclude, the significant value for XK-Lex is 0.029 (i.e. less than 0.05) which means that the English vocabulary knowledge makes a significant unique contribution to the performance of the CBIs, but the Arabic vocabulary knowledge score is greater than $0.05(0.400)$ which means it is not making a significant unique contribution to the performance of the CBIs. We assume that Arabic-Lex do not make a high significant contribution to the CBIT because the assessors have considered as a correct translation any attempt by participants regardless of whether the performance was high quality translation or not compared to the version given in the key answer.

\section{Participants' Performance in the CBIT}

The quality of professional translators' performance in the CBIT was below expectations (Figure 2), considering the participants were professional translators and they did not have time constraints in doing the test. Furthermore, they were allowed to use reference sources in translating the 
CBIs. Figure 2 presents the participants' overall scores in the CBIT, the XKLex, the Arabic-Lex. However, we did not present the procedures used for each $\mathrm{CBI}$ as there are very few responses to include them in the table.

As shown in Figure 2, all the 35 participants obtain low scores in the CBIT (the highest score is 53\%) even if they achieved high scores on their Arabic and/or English knowledge. Almost 23\% of participants are considered fluent in English as they achieve high scores between $80 \%-90 \%$, of XK-Lex (Nation 2006), while the rest of participants do not even reach the base level for translators.

Although the highest score in translating the CBIs is $53 \%$ obtained by one participant only, the participant attained high scores $77 \%$ and $83 \%$ in Arabic and English knowledge respectively. However, the participant named only one procedure. The second highest score is $47 \%$ obtained by two participants and their performance in Arabic knowledge is between $72 \%-92 \%$ and their English knowledge is between $77 \%$ - 85\%. One of them named 3 types of correct procedures and 3 types of incorrect procedures which is the highest number among participants. 7 participants are even lower as they scored between $37.5 \%$ and $22 \%$ in the CBIT; one of the participants named one incorrect procedure and invented one procedure, whereas the rest (22 participants) achieved between $19 \%$ and $3 \%$ in the CBIT. This group named one correct procedure, but 4 incorrect procedures and invented 2 procedures. 
Figure 2. Overall Scores of Participants in XK-Lex, Arabic-Lex and CBIT

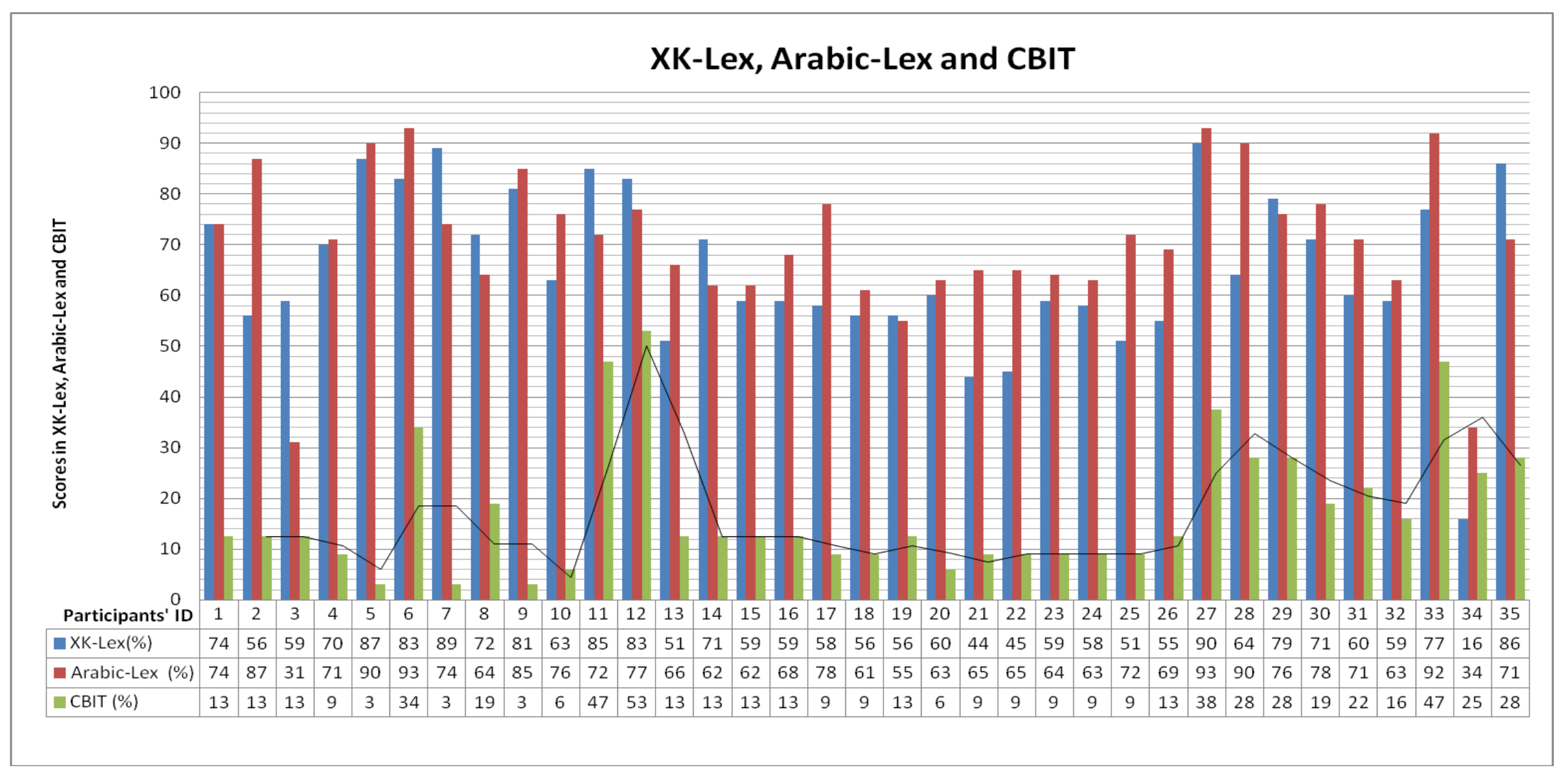


Acceptable Equivalents for the English CBIs

In our discussion of the correct and incorrect translations (see also Tables 15 and 16), we have referred to the answer key for the CBIT. Given the fact that no single perfect translation exists for a text, we considered as correct any attempt that provided an acceptable meaning, as shown in Table 14.

Table 14. Acceptable Translations

\begin{tabular}{|c|c|c|c|}
\hline ID & CBIs & $\begin{array}{c}\text { Translation into } \\
\text { Arabic }\end{array}$ & Back translation \\
\hline 1 & love me, love my dog & أحبني وأحب كلبي, & $\begin{array}{l}\text { love me and love my dog, love me } \\
\text { with all my faults }\end{array}$ \\
\hline 2 & convenience store & تموينات & grocer's \\
\hline 3 & innocent as a lamb & بريء كالطفل & innocent like a child \\
\hline 4 & three-course meal & وجبة متكاملة بثلاث & meal integrated three dishes \\
\hline 5 & $\begin{array}{l}\text { members of the house } \\
\text { of Lords }\end{array}$ & مجلس اللوردات & lords board/salon \\
\hline 6 & trick-or-treating & يمارسون طقوس الهالوين & practicing Halloween's ritual \\
\hline 7 & pardon my French & عذر أ على قلة أدب & sorry for my bad manner \\
\hline 8 & hooliganism & الشغب & riot \\
\hline 9 & Madame Tussauds & متحف الشمع & wax museum \\
\hline
\end{tabular}

Besides, we rank them on the degree of correct translations (i.e. cultural equivalence, calque, descriptive equivalence, paraphrase with gloss or note and transcription) as shown in Table 15 and erroneous translations (i.e. incorrect, under translation, omission, non-sense and opposite meaning).

Table 15. Types of Correct Response

\begin{tabular}{|c|c|c|c|c|}
\hline $\begin{array}{c}\text { Cultural } \\
\text { equivalence (1) }\end{array}$ & $\begin{array}{c}\text { Calque } \\
\text { (2) }\end{array}$ & $\begin{array}{c}\text { Descriptive } \\
\text { equivalence (3) }\end{array}$ & $\begin{array}{c}\text { Paraphrase } \\
\text { (4) }\end{array}$ & $\begin{array}{c}\text { Transcription } \\
\text { (5) }\end{array}$ \\
\hline 129 & 22 & 42 & 0 & 2 \\
\hline
\end{tabular}

The acceptable responses $(17.5 \%$ in total) were named in this table as correct; (1) cultural equivalence (129 responses), (2) calque (22 responses), (3) descriptive equivalence (42 responses), (4) paraphrase (0 responses) and (5) transcription (2 responses) giving a grand total of 195 acceptable responses out of 1,120 total responses. Although, the highest correct procedure used (cultural equivalence) was high, there are many CBIs that do not have equivalence in the TL; that needs to be given further explanation by in the footnote or gloss which none of the participants use.

Even though the translations of the CBIs in Table 14 may seem lexically, grammatically and semantically correct, this is not always the case. Some of the translations can be considered correct even if there are some lexical or grammar mistake: we made due allowances for the length of the test and the limited opportunity for revision and correction. In general, the participants do 
not communicate the full meaning in the TL. All these CBIs have been carefully selected to reflect British culture, which should be explained in the target culture by adding more information in a gloss or footnote. For example, the English CBI Pardon my French ${ }^{6}$, was translated into (عذراً على قلة أدب) the back translation is Sorry for my bad manner. With this attempt the participant has given the basic meaning without explaining the British association of French with bad language.

\section{Errors Made}

In this section, we discuss the types of errors (82.5\% of total) that Arabic professional translators made. Errors were categorised in Table 16.

Table 16. Types of Errors

\begin{tabular}{|c|c|c|c|c|}
\hline $\begin{array}{c}\text { Incorrect } \\
(\mathbf{1})\end{array}$ & $\begin{array}{c}\text { Under translation } \\
\mathbf{( 2 )}\end{array}$ & $\begin{array}{c}\text { Omission } \\
\mathbf{( 3 )}\end{array}$ & $\begin{array}{c}\text { Non-sense } \\
\mathbf{( 4 )}\end{array}$ & $\begin{array}{c}\text { Opposite meaning } \\
\mathbf{( 5 )}\end{array}$ \\
\hline 396 & 123 & 192 & 192 & 22 \\
\hline
\end{tabular}

These errors were named as incorrect: (1) incorrect translations, (2) under translation, (3) omission, (4) non-sense translations, and opposite meaning giving a grand total of 925 out of 1,120 in total responses. Further discussion of the incorrect translation will be found in Table 17. Generally, the highest incorrect score by three participants (31 mistakes out of 32 items) corresponded to scores in Arabic knowledge of $74 \%, 85 \%$, and $90 \%$ and English knowledge of $89 \%, 81 \%$, and $87 \%$ respectively which means the participants have a good level of vocabulary knowledge in both languages but they could not translate the CBIs correctly. The vast majority of errors we discovered in the results of translating the CBIs were as follows: first, incorrect translations (396); second, omission and non-sense (192), third, under translation (123) and finally, opposite meaning (22). Examples of the errors made are illustrated in Table 17.

\footnotetext{
${ }^{6}$ The source of the phrase is earlier and derives from a literal usage of the exclamation. In the $19^{\text {th }}$ century, when English people used French expressions in conversation they often apologised for it - presumably because many of their listeners (then as now) would not be familiar with the language.
} 
Table 17. Examples of Errors

\begin{tabular}{|c|c|c|c|c|}
\hline ID & English CBI & $\begin{array}{c}\text { Arabic } \\
\text { translation }\end{array}$ & Back translation & $\begin{array}{c}\text { Types of } \\
\text { errors }\end{array}$ \\
\hline 1 & The Big Issue & الحدث العظيم & The big issue & incorrect \\
\hline 2 & $\frac{\text { what the heck is }}{\text { going on? }}$ & ماذا & What & omission \\
\hline 3 & chop-chop & قطعه قطعه & Piece piece & non-sense \\
\hline 4 & convenience store & متجر لساعات & Store for long hours & $\begin{array}{c}\text { under } \\
\text { translation }\end{array}$ \\
\hline 5 & banana skin & خدمه للحكومه & $\begin{array}{l}\text { Service to the } \\
\text { government }\end{array}$ & $\begin{array}{l}\text { opposite } \\
\text { meaning }\end{array}$ \\
\hline
\end{tabular}

In example 1, one of the common errors made by participants is that they mistranslate the meaning by giving the literal translation of the text. The English CBI The Big Issue (i.e. a well-known magazine generally sold by homeless people to improve their lives) was translated literally into Arabic as (العظيم الحدث), the back translation is being the big issue, without any indication that this was the title of a magazine. The CBI was underlined and the participants had the time and the resources to translate the CBIs. Some of these CBIs were selected because a literal translation was possible, while others could not be translated literally. However, the results show that there is lack of knowledge of CBIs.

The second type of error is deleting or omission while rendering the CBI into the TC, where an essential element in the SL is usually missed. In example 2, what the heck is translate into Arabic as ماذا, the back translation is what. Also, another error made by participants is non-sense translation. In this study, we refer to it as a third language: it is a highly important type of error in translation since the target text reads like a "foreign" language and it "sounded wrong" (Duff 1981: xi). In example 3 the English CBI is chop-chop is translate into Arabic as (قطعه قطعه); the back translation is piece piece which obviously does not provide any sense for the text.

The third type of error is under translation. This results when the translator fails to be it sufficiently explicit in the translation requirement to give a clear picture of the CBI. In example 4 the English CBI, convenience store, is translated into Arabic as (متجر لساعات طويلة) the back translation is store for long hours where translator translate part of the meaning as the store open for long hours but s/he miss to render that the store is located in some convenient areas.

The last type of error made is when the translator gives an opposite meaning (Baker 2011) where both cultures have the same image but they perceive it differently as one culture uses this image for negative purpose while the other uses it for positive purpose (example 5). This is a serious error in translation since it violates translation ethics. This happens when the images used exist in both languages but are perceived differently as they have different meanings (Aldhahi et al. forthcoming). It is a major area of difficulty since the translator thinks that $\mathrm{s} / \mathrm{he}$ recognises the expression which leads him/her to mistranslate - as strong as an $o x$. An English speaker will perceive it positively as a complement for strength, while an Arabic speaker will perceive it negatively - the ox is strong but not smart 
(stupid, does things without thinking!). For instance, in example 5 the English CBI banana skin, is translated into Arabic as (خدمه للحكومه), the back translation being service to the government, which obviously gives the totally opposite meaning to that of the text.

Commonly, the highest types of mistakes appear as incorrect translation (396) responses which mean that there is misunderstanding of the CBIs and this shows the need for more training programmes on translating CBIs. Then, the second highest scores are both omission and non-sense translations consisting of 192 responses, which means that if a CBI appears in a text and they do not understand its meaning, the translators overlooked the stylistic and the colourful aspect of the text or translated it into an awkward text that the target readers cannot understand; which might be considered as a "third language" or "translationese" (Duff 1981). The third common mistake appears as under translation (123 responses). Translators may understand the CBI within a text but do not have full understanding, so that subsequently they could not give an adequate explanation when needed. The last type of error appears as the translators give an opposite meaning (22 responses). Even though very few translators make this mistake, it is rather serious and represents a significant challenge in translating.

\section{Measuring their Knowledge of Procedures Used in Translating the CBIs}

In our test, we asked participants to provide the types of translation procedures they used in each CBI translated and we give a list of good procedures for translating such matter. Only $20 \%$ of participants responded to this question. Even those who named the appropriate procedures (Table 18) to use in translating the CBIs did not use them correctly, as illustrated in Table 19.

Table 18. The Type of Procedures Provided by Participants

\begin{tabular}{|c|c|c|c|}
\hline ID & Correct & Non-preferable & Incorrect \\
\hline 1 & $\begin{array}{c}\text { communicative } \\
\text { translation }\end{array}$ & word to word translation & personal translation \\
\hline 2 & transcription & one to one translation & Google translate \\
\hline 3 & idiomatic translation & omission & componential analysis \\
\hline 4 & paraphrase & literal translation & deculturalization \\
\hline 5 & descriptive & formal equivalence & - \\
\hline 6 & calque & deletion & - \\
\hline
\end{tabular}

These results show about $37.5 \%$ are correct and $62.5 \%$ are incorrect which emphasises the need to educate translators in translation strategies and procedures as this highlights the challenges for professional translators in translating the CBIs. Further discussion of their performance and the procedures recommended is given in Table 19. 
Table 19. Misuse Use of Procedures

\begin{tabular}{|c|c|c|c|c|}
\hline ID & English CBI & $\begin{array}{c}\text { Procedures } \\
\text { recommended by } \\
\text { participant }\end{array}$ & $\begin{array}{c}\text { Arabic } \\
\text { translation }\end{array}$ & Back translation \\
\hline 1 & car boot sales & $\begin{array}{c}\text { Descriptive/ } \\
\text { deculturalization }\end{array}$ & بيع من صندوق & $\begin{array}{l}\text { sale from the car } \\
\text { trunk }\end{array}$ \\
\hline 2 & $\begin{array}{l}\text { estuary } \\
\text { English }\end{array}$ & Paraphrase & اللكنه الجنوبية & southern accent \\
\hline 3 & number 10 & Calque & الرقم 10 & number 10 \\
\hline 4 & $\begin{array}{c}\text { love me love } \\
\text { my dog }\end{array}$ & $\begin{array}{l}\text { Componential } \\
\text { analysis }\end{array}$ & أحبني وأحب كلبي, & $\begin{array}{l}\text { love me love my } \\
\text { dog, love me with } \\
\text { all my faults }\end{array}$ \\
\hline 5 & $\begin{array}{l}\text { love me love } \\
\text { my dog }\end{array}$ & $\begin{array}{l}\text { Idiomatic } \\
\text { translation }\end{array}$ & من يحبني يحب كلبي & $\begin{array}{l}\text { who loves me loves } \\
\text { my dog }\end{array}$ \\
\hline
\end{tabular}

The examples in Table 19 show that some of these CBI have not used the appropriate procedure(s). For instance, in example 3 Number 10, the participant chose the procedure calque which can be used but we cannot use it alone as the meaning will not be clear for the TC. We could use calque and descriptive in order to introduce the English CBI to Arabic culture with some more explanations to be understood. Another noticeable feature is that, although some of the participants indicated the appropriate procedures for the CBI as shown in example 2 and 5, they did not use it in practice.

\section{Limitations of the Study}

This study may have been constrained by two factors related to the participants. First, there is no data base for the professional translators in the KSA; therefore, it was difficult to determine the suitable minimum number of participants of professional translators in KSA in different sectors, which also caused some difficulty in the Saudi case. Second, the professional translators who work in the TC (i.e. the UK) did not respond even though we pursued different social networks such as the origination website and the individual accounts in LinkedIn, Twitter and emails.

\section{Summary and Conclusions}

Translating can pose a wide range of challenges to translation, e.g. semantic, pragmatic, etc, but this research aims to contribute to the challenge of translating cultural content from one language to the other by focusing on the translation of what we term CBIs (culture-bound items). By CBI we mean conventionalized expressions, often prefabricated and with non-compositional meaning, which are not necessarily difficult to understand but which can pose significant challenges in translation. Expressions such as trick or treat and love me, love my dog in English and لا ناقة لي فيها ولا جمل (neither a female nor a 
male camel", i.e. "this matter does not concern me") in Arabic are examples in point. Some CBIs pose even more significant challenges to translation because there is no obvious equivalent in the target language or culture, e.g. golf widow when translating from English into Arabic, and كمسمار جح ("like Juha's nail", an expression used to refer to something that has become a vacuous excuse) when translating from Arabic into English.

In this paper, we aimed to explore whether it is possible to predict the level of cultural competence needed in order to avoid making errors when translating CBIs such as the above and, if so, to what extent. To this end, we used the English and Arabic vocabulary tests designed by Masrai and Milton (2012 and in press) to determine the language proficiency of participants. We also designed a cultural translation test (CBIT) in which participants would translate CBIs in both directions between English and Arabic and provide us with some feedback as to the procedures they were following to translate them.

The vocabulary tests (XK-Lex and Arabic-Lex) together with the CBIT constituted the survey we used with Arabic professional translators in Saudi Arabia. We selected professional translators rather than trainee translators or other groups as our participants because a priori it would be reasonable to expect that professional translators would have an excellent command (at least in theory) of both English and Arabic, in this case. In total, we surveyed 35 Arabic professional translators. We did not have sufficient responses from English-speaking professional translators to include them in this research.

The analysis of our survey shows that there is a wide range of scores among the translators. While the majority of translators scored high or relatively highly in both vocabulary tests, others scored rather below our expectations for professional translators, e.g. one translator $(2.8 \%$ of the 35 surveyed) scoring 16\% in the XK-Lex and 34\% in the Arabic-Lex. This means that this participant scored very low even in Arabic, which is his/her native language, although all other translators scored much higher. Further, the average vocabulary size of the surveyed translators is around 6,500 words, somewhat lower than the figure of 8,000-9,000 words proposed by Nation (2006) to comprehend written discourse. In any case, even if some translators achieved high scores in both vocabulary tests, only three translators (8\%) achieved scores of $40 \%$ or more in the cultural translation test. Overall, translators managed to translate correctly just over $17 \%$ of the total number of CBIs. The highest score in the CBIT was 53\% which, again, was much lower than we anticipated.

The findings of our survey suggest that the vocabulary knowledge of our participants was generally below what might be expected from professional translators and that there was a strong correlation between obtaining low vocabulary scores and obtaining low scores in the CBIT. Even though our data set is relatively small, it highlights trends that have also been found by other studies, such as Bahumaid (2010). Although Bahumaid investigated translator trainees, he also reported low scores in the translation of CBIs. Therefore, our findings emphasise the overall need for further cultural training and for increased cultural awareness for translators. 
Although it is difficult to pinpoint the specific level of cultural competence achieved by translators at any one time, our results indicate that our cultural translation test, or CBIT, can provide useful general indications of where this level lies for a particular cohort. For example, the level of cultural competence of our participants was generally very low, on the basis that only 3 translators $(8.5 \%)$ scored $40 \%$ or higher in the CBIT. Further data and wider testing will be needed in order to confirm and validate these results. However, we hope to have raised some awareness about the importance of including further cultural training in translator training programmes.

We also hope to have shown that, in our specific English-Arabic language combination, further in-depth training for translators in their first language, not only in English, would be particularly beneficial, as translators need to be not only sophisticated writers of the target language but also sophisticated readers of the source language, especially when it comes to cultural content.

\section{Acknowledgments}

We would like to express our appreciation to the Saudi Culture Bureau in the UK for providing the funding for this research and also to Swansea University for all their support.

\section{References}

Abdel-Hafez A (2004) Cultural Elements in the Translation of Mahdfooz's "The Beginning and the End and Palace of Desire." Internet-Zeitschrift fur Kulturwissenschaften 15. Retrieved from goo.gl/7MTbMY. [Accessed: 15 November 2015].

Aldhahi M, Davies L, Fernandez-Parra $M$ (forthcoming presentation in MICOLLAC 2016) Educating Translators: Increasing Cultural Training for Professional Purposes.

Alghamdi R (2016) Translating Religious Terms and Culture in "The Sealed Nectar". Doctoral dissertation, University of Leeds, UK.

Alkadi T (2010) Issues in the Subtitling and Dubbing of English-Language films into Arabic: Problems and Solution. Doctoral dissertation, Durham University, UK.

Al-Masrai H (2009) Translation and Cultural Equivalence: A Study of Translation Losses in Arabic Literary Texts. Journal of Language \& Translation 10(1): 7-44.

Alowedi NA (2015) Developing A Translator Career Path: A New Approach to InHouse Translator Development Evaluation. Doctoral dissertation, Kent State University, USA.

Anglin J (1993) Vocabulary Development: A Morphological Analysis: Monographs of the Society for Research in Child Development, Serial No. 238. Chicago: University of Chicago Press.

Awwad M (1990) Equivalence and Translatability of English and Arabic Idioms. Papers and Studies in Contrastive Linguistics 26(57): 57-67. 
Aziz Y (1985) Modes of Address in English-Arabic Translation. Babel 31(3): 144146.

Aziz Y (1999) Cross-Cultural Translation and Ideological Shifts. International Journal of Translation 2(1-2): 29-84.

Bachman LF (2004) Statistical Analyses for Language Assessment. Oxford: Oxford University Press.

Bahumaid S (2010) Investigating Cultural Competence in English-Arabic Translator Training Programmes. Meta: Journal des traducteurs; Meta: Translators' Journal 55(3): 569-588.

Baker M (2011) In Other Words: A Coursebook on Translation. London: Routledge.

Barkho, L. Y. (1987): Cultural Problems of Arabic-English Political Translation. Babel. 33(3):143-151.

Brown AD (2006) A Narrative Approach to Collective Identities. Journal of Management Studies 43(4): 731-753.

Childs P, Storry M (Eds.). (2013) Encyclopedia of Contemporary British Culture. London: Routledge.

Christopher DP (2015) British Culture: An Introduction. London: Routledge.

Chung H (2006) GlobalMind - Bridging the Gap Between Different Cultures and Languages with Common-sense Computing. Doctoral dissertation, Massachusetts Institute of Technology, USA.

Cometa M (2004) Parole che dipingono (Words that paint). Letteratura e cultura visuale tra Settecento e Novecento, Meltemi, Roma.

DeVellis RF (2016). Scale Development: Theory and Applications (4 ${ }^{\text {th }}$ edn.). Thousand Oaks, California: Sage Publications, Inc.

Duff A (1981) The Third Language: recurrent problems of translation into English : it ain't what you do, it's the way you do it. Oxford and New York: Pergamon Press.

Farghal M, Borini A (1996) Pragmalinguistic Failure and the Translatability of Arabic Politeness Formulas into English: A Case Study of Mahfouz's Awlad Haritna. INTERFACE: Journal of Applied Linguistics 11(1): 3, 23.

Faiq S (1998) Handling Metaphor in Sensitive Texts: Contributions from ArabicEnglish Translation. Translation 17(3): 224-239.

Faris AAH, Sahu RA (2013) The Translation of English Collocations into Arabic: Problems and Solutions. Journal of the College of Arts. University of Basra (64): 51-66.

Fenton N, Neil M (2012) Risk Assessment and Decision Analysis with Bayesian Networks. London: CRC Press.

Fernández-Parra M (2014) Formulaic Expressions in Computer-Assisted Translation: A Specialised Translation Approach. Saarbrücken: Scholars' Press.

Ghazala H (2006) Translation as Problems and Solutions: A CourseBook for University Students and Trainee Translators. Beirut: Dar wa Maktabat Al-Hilal.

Gläser R (1984) The Translation Aspect of Phraseological Units in English and German. Papers and Studies in Contrastive Linguistics Poznan 18: 123-134.

Glođjović A (2010) Translation as a Means of Cross-Cultural Communication: Some Problems in Literary Text Translations. Facta universitatis-series: Linguistics and Literature 8(2): 141-151.

Hickey L (Eds.). (1998) The Pragmatics of Translation. (Vol. 12). Clevedon: Multilingual Matters.

Home Office (2013) Life in the United Kingdom - A Guide for New Residents (3 ${ }^{\text {rd }}$ edn.). TSO.

Homeidi MA (2004) Arabic Translation Across Cultures. Babel 50(1): 13-27. 
Kehal M (2010) Problems in English Arabic Translation of Reference Pragmatic Aspects. Master thesis. Mentori University, Algeria. Retrieved from goo.gl/rGZTMI.

Mahdi AM, Yasin MSM (2015) Translating Collocations from English to Arabic among Iraqi EFL Learners. English Language and Literature Studies 5(3): 57.

Marías J (2012) A Heart So White, trans. Margaret Jull Costa. London: Harvill.

Masrai A, Milton J (2012) The Vocabulary Knowledge of University Students in Saudi Arabia. TESOL Arabia Perspectives 19(3): 13-20.

Masrai A, Milton J (in press). How Many Words Do You Need to Speak Arabic? An Arabic Vocabulary Size Test. The Language Learning Journal.

Milton J, Treffers-Daller J (2013) Vocabulary Size Revisited: The Link Between Vocabulary Size and Academic Achievement. Applied Linguistics Review 4(1): 151-172.

Mitchell WJT (1994) Picture Theory: Essays on Verbal and Visual Representation. Chicago, IL: University of Chicago Press.

Mustafa BA (2010) Collocation in English and Arabic: A Linguistic and Cultural Analysis. College of Basic Education Researches Journal 65: 29-43.

Nation I (2006) How Large a Vocabulary is Needed for Reading and Listening? Canadian Modern Language Review 63(1): 59-82.

Nord C (2005) Text Analysis in Translation: Theory, Methodology, and Didactic Application of a Model for Translation-oriented Text Analysis, No. 94. Amsterdam: Rodopi.

Olwi A (forthcoming) Subtitling the Taboo Is It a Taboo? Doctoral dissertation, Swansea University, UK.

Ordudari M (2007) Translation Procedures, Strategies and Methods. Translation Journal 11(3): 8.

Pym A (2016) Translation Solutions for Many Languages: Histories of a Flawed Dream. London: Bloomsbury Publishing.

Ramli WNHW (2014) The Translation of Simile in the Hunger Games Novel: Translation Strategies. E-proceedings of the Conference of Management and Muamalah (CoMM 2014), 26-27 May 2014, pp. 373-378.

Samardali M, Al Momani M, Kitishat AR (2013) An Investigation into some Pragmatic and Cultural Problems in Translating Arabic Implicature into English: A Case Study Of Jaradat's "HABILAT BISHRA". Research Journal of Social Science and Management 3(3): 161-171

Shamsaeefard M, Fumani MRFQ, Nemati A (2013) Strategies for Translation of Similes in Four Different Persian Translations of Hamlet. Linguistics and Literature Studies 1(3): 164-168.

Shunnaq A (2000) Arabic-English Translation of Political Speeches. Perspectives: Studies in Translatology 8(3): 207-228.

Smith J (2012) Exploring British Culture: Multi-level Activities about Life in the UK. Cambridge: Cambridge University Press.

Wray A (2002) Formulaic Language and the Lexicon. Cambridge: Cambridge University Press.

Zanoletti M (2012) Translating an Artwork: Words and Images. In R Wilson, B Maher (eds.), Words, Images and Performances in Translation. London: Continuum. 


\section{$\underline{\text { Appendix A }}$}

\section{English XK-Lex Vocabulary Test}

Please look at these words. Some of these words are real English words and some are not but are made to look like real words. Please tick $(\checkmark)$ the words that you know or can use. Here is an example.

\begin{tabular}{|c|c|c|c|c|}
\hline New & commerce & organise & accuse & victory \\
\hline Gummer & tindle & wookey & candish & skave \\
\hline Word & dust & fountain & tend & jewel \\
\hline Near & nonsense & movement & landing & reliable \\
\hline Peace & fond & likely & volume & harden \\
\hline Produce & sweat & provide & tube & sorrow \\
\hline You & cap & castle & liner & dial \\
\hline Wife & worry & steam & previous & enclose \\
\hline Do & plenty & steady & style & sneeze \\
\hline Add & guide & pole & outline & apparatus \\
\hline Kilp & broy & orrade & plaudate & overend \\
\hline Build & pump & guest & keeper & roast \\
\hline & & & & \\
\hline Prosecutor & addict & gulp & idleness & carnation \\
\hline samphirate & treadway & darch & callisthemia & mordue \\
\hline Referral & detachment & thud & blizzard & plaintively \\
\hline Illuminate & unsure & assassin & rut & gurgle \\
\hline Gown & reinforcement & wrench & incessant & heal \\
\hline Verge & enlightenment & backdrop & blunder & allure \\
\hline Counsellor & workman & unfold & springboard & atone \\
\hline Skipper & feudal & upheaval & shrapnel & locket \\
\hline Authorise & quartet & animation & skip & nudge \\
\hline Sour & psychic & banish & bastion & barn \\
\hline Neminary & fallity & treggle & snape & tearle \\
\hline Holly & appropriation & peninsula & maroon & contrive \\
\hline & & & & \\
\hline
\end{tabular}

Thank you for your help! 


\section{$\underline{\text { Appendix B }}$}

Section two: (2-2)

\section{Arabic-Lex Vocabulary Size Test A (50K)}

Please look at these words. Some of these words are real Arabic words and some are invented but are made to look like real words. Please tick the words that you know or can use, also provide a meaning of a given word or use it in a short sentence. Here is an example.

\section{book $\checkmark$ I read a book.}

من فضلك انظر الى هذه الكلمات. بعض هذه الكلمات هي كلمات عربية حقيقية و البعض الآخر كلمات تم

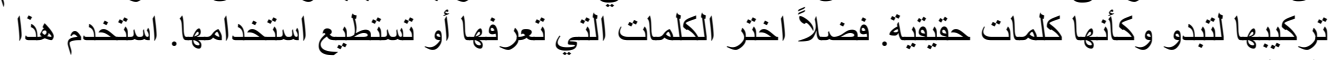

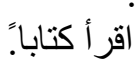

\begin{tabular}{|c|c|c|c|c|}
\hline إسْنَتَرَرت & نزْكَب & حُكَّام & أكَاد & نَشْرْ \\
\hline تُسنَوِّغ & انَقَضَنَ & أخبَارَ هُمْ & زَئبقَ & عُنْف \\
\hline نَافِدِ & استِنِنهَاض & نُصُوصنَا & تفَارُقْ & دَقَ \\
\hline الاسنمَى & المَلَمَس & يرِْْي & مَحَفْلَ & شُبْْهُة \\
\hline امْكَانِيَهَ & سأنتُم & أَعْنَى & مَحَلُْ & سَائقِ \\
\hline مِتِنْرَار & إِفْتصنَ & مُناقَّسة & فترَاف & تَمَوْ ح \\
\hline الإقِتِدَداء & يمْدَح ح & مَشُْطُوبوب & مُعْطُى & جَرْو \\
\hline انْتَنَرَ & انْبِحَاقَ & مَنْزِ لَهُمْ & غَمَضَ & عُطْلْ \\
\hline اوْضَّاعهَا & الامنتِلاء & اسْنَتَدِيِي & أَغَرِّ & الأربِعاء \\
\hline عُعَّاد & آخَر & خَافِق & أَعْنَاقَ & حُمْرز \\
\hline نُحِقِقهـ & تَهَثَشَ & أخُوُض & ضضَامَ & مَحَاوِر \\
\hline إِعْتكاب & دُرُوغُغ & سَكَكِيم & اَحْتِماكَ & قَغْرْ \\
\hline آَفَاَُقهَا & رمَشَتْنْ & افْترَىَى & كَيْنُونَة & عَطْف \\
\hline تَتَرَوَاح & تُبِْْضْ & مُوَْْى & ارْجُوكُم & مُنََّفَىَى \\
\hline اوَ اجِهـ & لايكُفِي & احترَ امَهُمْ & ذَرَفتَ & تجَوَلَ \\
\hline ذَذِمَام & مُؤسَسَتَاتِيَة & الفضَتائلِل & بتَسَتَاءَلوُُن & تَكَكُلْ \\
\hline الأمْنِيَاتَ & نَابِعاً & مهَالِلك & مُسْنَخَخْنَر ات & تألَّقَ \\
\hline إنْزْ لام & إتحَال & زَوَاخَ & كتّاج & احجتْر اذ \\
\hline بَنْفُتُ & أُجْنَتَع & يَنْشْدُ & مَائدِة & الغِيْرِ \\
\hline مُفَفَنَب & أقُصَّاه & صدَقَّة & يُحَافِظٍ & صنَنْ \\
\hline خَلَوفْ & أَرَشِح & الإنتِقَّام & انتِحَال & كَلا \\
\hline نَعْرَة & مسنألْتِي & بِأَكْمَلِهِ & أفلاًم & فَرَ \\
\hline اسْنَطُاب & أَثْفَى & تَعَبْيْرَرَ هُمْ & الأسنَرَة & استِحْدَاث \\
\hline تمُرِيز & إِنِرَاح & صَاحِر & مُضَاهدَات & إِجِماج \\
\hline
\end{tabular}

Thank you for your help! 


\section{$\underline{\text { Appendix C }}$}

\section{Section three:}

You are to translate the following expressions. Bearing in mind the context, purpose and readership of the target text, give the most appropriate Arabic renditions of the underlined English words or expressions that are marked in bold type. Mention the translation procedures (e.g. borrowing, adaptation, paraphrase, omission, addition, Calque, etc.) you have used in translating each expression as possible. Write your answers in the spaces provided on the test.

1. It's just that when I call my electricity provider I rather hope to hear a London accent, or perhaps even a grating example of estuary English.

2. There aren't many people in the UK who would say that business is booming, but it seems that hard times are good times for car boot sales

3. The jobs came online in the spring with the opening of a new convenience store at the supermarket's old base in the town centre.

4. Being a golf widow you will often find that you benefit from ancillary golfing possessions.

5. If Number 10 is not worrying about this nobody else will.

6. "Two pints, chop-chop," Jimmy called.

7. What the heck is going on?

8. The Big Issue has truly changed my life; it has given me hope that there is a better future for myself and my partner.

9. Jill: I wish you'd keep your dog out of the house when I come over. Jane: Love me, love my dog.

10. During the blizzard we had plenty of firewood and stayed in the cottage, snug as a bug in a rug.

11. Mary is as nutty as a fruitcake if she thinks she can get away with that.

12. I don't like opera. I avoid it like the plague.

13. Hey! You can't throw me in jail," cried the robber. "I'm innocent as a lamb.

14. The politician kept cool as a cucumber throughout the interview with the aggressive journalist. 
15. Members of the House of Lords bring experience and knowledge from a wide range of occupations.

16. An Englishman would interrupt a war to have his cream Tea.

17. I realize a fantasy computer game is not everyone's cup of tea, but this one is amazing.

18. Police said he acted like a lager lout and hit an officer.

19. Kids are going to go trick-or-treating tomorrow night.

20. Rob's like a bull in a china shop, don't let him near those plants.

21. I thought you were being serious - I didn't realise you were taking the mickey.

22. The new tax has proved to be a banana skin for the government.

23. I'm so sorry I'm late. I couldn't get away from Linda. She can talk for England!

24. Pardon my French, but this is a hell of a day.

25. Much as I love this Indian summer, I wish we had had this warm weather in the summer rather than in October.

26. Spoil your loved one with a three-course meal whether it's a spontaneous gesture or a Valentine's Day treat.

27. A "real Punk" will never stereotype themselves/herself.

28. Get your skates on! We're going to miss the train.

29. Many tourists come to London to visit Madame Tussaud

30. Police investigating football hooliganism

31. Things are never dull when she stirs her stumps to create a mild uproar in that pompous little town. 